\title{
Field investigations and multi-indicators for shallow water lagoon management: perspective for societal benefit
}

\author{
Patrice Brehmer ${ }^{1, *}$, Thang Do $\mathrm{Chi}^{2}$, Thierry Laugier ${ }^{3}$, François Galgani ${ }^{4}$, Francis Laloë ${ }^{5}$, Audrey M. \\ Darnaude $^{2}$, Annie Fiandrino ${ }^{3}$, David Mouillot ${ }^{2}$
}

\author{
${ }^{1}$ IRD, UMR LEMAR (CNRS, UBO, IRD), Plouzané, France \\ ${ }^{2}$ Université Montpellier 2, UMR ECOSYM (CNRS, IRD, Ifremer), Montpellier cedex 5, France \\ ${ }^{3}$ IFREMER, LER-LR, Sète cedex 1, France \\ ${ }^{4}$ IFREMER, ZI Furiani, Bastia, France \\ ${ }^{5}$ IRD, UMR GRED (UM3, IRD), Montpellier Cedex 5, France \\ *: Corresponding author : Patrice Brehmer, email address : Patrice.Brehmer@ird.fr
}

\section{Abstract :}

1 Abiotic and biotic variables of coastal lagoons are highly heterogeneous in both space and time, and this heterogeneity complicates the assessment of their ecological status. These variables are essential to the monitoring and preservation of these fragile ecotones and the resources and services they sustain.

2 An integrative approach for evaluating the ecological status of coastal lagoons, based on field investigations of the key parameters driving their functioning and a set of selected ecological indicators matching lagoon management information needs for societal benefits, is investigated. Consistency in lagoon status evaluation from multiple and different variables was estimated, through a case study comparing three adjacent yet contrasting French Mediterranean shallow water lagoons.

3 French Mediterranean shallow water lagoons are used to demonstrate the potential of such an approach and to underline the need for a multi-faceted framework, for correctly evaluating lagoon status, and underlining the need for high-frequency lagoon monitoring to avoid errors in status assessment and resulting management plans.

4 Based on the results, a continuous monitoring system is proposed that would record high frequency biotic and abiotic data in the lagoons. The use of such an ad hoc observatory system, based on appropriate diagnostic indicators and risk estimators would simplify interactions between scientists and managers and would improve the efficiency of their analyses.

5 A lagoon management plan based on a holistic approach is proposed to help scientists and local managers to reach a consensus about the set of ecological indicators to monitor in the lagoons needed to assess their 'global health' status in accordance with both conservation and/or societal needs.

Keywords : coastal lagoon ; ecological assessment ; ecotoxicology ; eutrophication ; indicator ; management ; Mediterranean Sea ; observatory 


\section{Introduction}

Coastal lagoons are located at the land-sea interface and are generally characterized by high biological productivity and shallowness. They are used by many fish and bird species, either as feeding, nursery or spawning grounds (Constanza et al., 1997; Oertli et al., 2005), and are therefore sometimes classified as protected areas (Agardy et al., 2003). With the rapid increase in use of lagoons for fishing, aquaculture and tourism (Sousa et al., 2009), and the increasing urbanization of the littoral zone, local decision makers and managers are increasingly faced with pressing management issues (Conley et al., 2009). Decision making is complicated by the variety of parameters and end-users that need to be considered in order to achieve optimal lagoon management e.g. fisheries management, aquaculture development, prevention of anoxic events and harmful algal blooms, channel closure, creation of protected areas, etc. Assessing the societal value of lagoon ecosystems, which are strongly impacted by anthropogenic activities (Lotze et al., 2006; Nixon et al., 2007), has to combine climatic and watershed data with appropriate descriptors of the biotic and abiotic characteristics of both the pelagic (water column) and the benthic (sediment) components of lagoon ecosystems (Souchu et al., 2000). This requires the combination of many scientific disciplines, such as climatology (Payraudeau, 2002), hydrology, macrobenthic ecology (Mouillot et al., 2005), fisheries assessment (Brehmer et al., 2006a) and as suggested recently, ecotoxicology, through the development of biotests and biomarkers to assess the impact of anthropogenic pollution (Losso and Volpi Ghirardini, 2010).

The goal of this work was to investigate the worth of the combined use of a comprehensive set of existing methods, all commonly applied in hydrology, ecology or fishery science, for improving the estimation of lagoon ecological and societal value. Through a case study involving the comparison of three different lagoons, the aim of this study was to identify the ad hoc methods to be included in effective real-time monitoring of coastal lagoons at the local scale, to allow optimization of societal benefits while still ensuring sustainable management of a lagoon within the frame of the European Marine Environmental Policy (Howarth, 2008).

\section{Materials and methods}

Evaluation of lagoon ecological status in the present work was based on field investigations of the key parameters driving lagoon ecosystem functioning and a set of selected ecological indicators matching the main information needs for sustainable management of lagoon resources. For this, the multi-disciplinary results from several scientific studies, all conducted simultaneously in 1999 on three adjacent temperate coastal lagoons, were combined. The first study, was mainly based on the recurrent annual monitoring of lagoon sediment, water column and macrozoobenthos characteristics, aimed at assessing lagoon eutrophication status. By studying current velocity and direction in the main entrance channels for each lagoon, this information was completed with data on water renewal and connectivity in these shallow and confined environments. Meteorological conditions were also recorded in 1999 (Brehmer et al., 2006a), as were water temperature and salinity in the three lagoons and in their entrance channels (Appendix A). This basic information on the environmental conditions in the lagoons was completed by ecotoxicological study conducted on bivalves, and a comprehensive description of fish diversity, abundance and their migratory behaviour in each lagoon in order to assess lagoon suitability for 
both aquaculture and fishery activities. All these data are the minimum required for lagoon management and enabled us to evaluate lagoon status.

\subsection{Experimental sites}

The three temperate coastal lagoons studied (Or, Prévost, and Ingril lagoons) are located within a $50 \mathrm{~km}$ distance along the French Mediterranean coast (Figure 1a). They are all shallow ( 0.6 to $1 \mathrm{~m}$ depth in average), connected to the sea each through a single channel and bordered by the Rhone to Sète Canal, with which they all communicate through several breaches. They vary in surface area $(3167,380$ and 549 ha, respectively) and anthropogenic pressures, especially since the Ingril and the Prévost lagoons lie in a different watershed to the Or lagoon (Figure 1b). The different environmental conditions between the three sites (Anonymous, 2002), makes them good candidates to investigate the value of the methodology proposed here.

\subsection{Water exchange with the sea}

Each lagoon is connected to the sea through a channel, where water current intensity and direction were recorded during acoustic surveys (see below). Observations in each channel were conducted over $24 \mathrm{~h}$ cycles in September, October, and November 1999. To compare current flows diel trends, hourly current intensity and direction data were processed for each 'month-site' combination using a Fourier linear model with five harmonics:

$$
Y_{i j t}=a_{i j o}+\sum_{k=1}^{5} a_{i j k} \cos (2 \pi k t / T)+\sum_{k=1}^{5} b_{i j k} \sin (2 \pi k t / T)+\varepsilon_{i j t}
$$

where $i$ is the lagoon, $j$ is the month, $t$ is the hour between 0 and 24 , and $k$ the harmonic.

The oriented current velocity $Y$ (in $m s-1$ ) produced by the Fourier linear model thus corresponds to the average hourly current speed in the channel, expressed as positive when the direction of the flow is toward the lagoon, and as negative when away from the lagoon.

\subsection{Environment quality}

Abiotic and biotic environmental quality data for the three lagoons were gathered in 1999 within the framework of the annual surveys undertaken by the Lagoon Eutrophication Monitoring Network (LEMN), which is in charge of the assessment of lagoons' eutrophication status for the whole Languedoc-Roussillon area (http://rsl.cepralmar.com/). Following the protocol developed by the LEMN (Souchu et al., 2000; Anonymous, 2002), five ecosystem compartments were considered for the assessment of lagoon ecological quality: water column, phytoplankton, macrophytobenthos, sediment and invertebrate macrofauna (Table 1). Global state diagnosis for each lagoon was thus based on a combination of indicators of water and sediment quality and the consequences of eutrophication on primary producers (phytoplankton and macrophytes) and benthic communities (Souchu et al., 2000). It allowed determination of each lagoon's environmental quality according to five levels of increasing eutrophication status (Table 1, Appendix B), ranging from excellent (pristine ecosystem) to bad (heavily eutrophicated ecosystem). To complete these data, independent measurements of the sediment RedOx potential (Schüring et al., 2000) were made at three stations within each lagoon (average in $\mathrm{mV}$ ). 


\subsection{Fish production and diversity}

In order to assess fish diversity (Mouillot et al., 2005), and calculate mean capture per unit of effort (CPUE) for the main commercial species (Brehmer et al., 2006a) in the three lagoons, three scientific sampling campaigns were conducted in February, May and September 1999 (150, 180, 200 samples respectively), using fyke nets to capture the fish (see Appendix C). For most of the migrant fish species listed in the three lagoons, May corresponds to the period for juveniles' settlement in the lagoons, and September to the beginning of their backward migration to the sea (see Brehmer et al., 2006a). In February, only the sedentary species are present in the lagoons. Therefore, fish sampling on these three dates covered most of the variability in fish diversity and productivity in the lagoons. However, to estimate the CPUE for the most important commercial species in the three lagoons (i.e. Anguilla anguilla, Dicentrarchus labrax, Sparus aurata, Atherina boyeri and Mugilidae), data were collected by monthly surveys of fish landings, conducted from January to December 1999 (Brehmer et al., 2006a).

For each site and date, species richness was calculated based on the data from the scientific surveys. Finally a diversity index, the average taxonomic distinctness $\Delta^{+}$was calculated (Clarke and Warwick, 2001), which is based on the taxonomic relationship between species:

$$
\Delta^{+}=2 \frac{\sum \sum_{i<j} \gamma_{i j}}{S(S-1)}
$$

where $S$ is the species richness and $\omega_{i j}$ is the distinctness weight given to the path length linking species $i$ and $j$ in the hierarchical classification.

\subsection{Fish acoustic tracking by horizontal beaming}

To assess the contribution of each lagoon to offshore fish stocks, fish movements within the lagoon entrance channels were investigated during the autumn, i.e. the period when most marine migrant species return at sea after several months of lagoon life (Gonzalez and Gerlotto, 1998). Three $24 \mathrm{~h}$ acoustic telemetry experiments were conducted in the channel of each lagoon, in September, October and November 1999 (see Appendix A), using stationary horizontal transducers (Krumme and Saint-Paul, 2003) installed on the channel bank (Figure 2). All details regarding the sampling methodology for these surveys can be found in Brehmer et al. (2006a). A split beam echosounder (Simrad EY $500(70 \mathrm{kHz})$ ) was used to measure the target strength of individual fish (Ona, 1999) and to 'echo count' (Simmonds and MacLennan, 2005) the number of fish travelling through the channel in both directions. To avoid the collection of non-biological data, only four successive pings were recognized as fish detection, the minimum distance between two targets was set at $30 \mathrm{~cm}$ and the dynamic tracking of each target allowed one ping to be missing. Net outgoing fluxes of fish (upstream minus downstream) were calculated for each lagoon as an indicator of fish transfer to the sea. To obtain more detailed information about fish schools (Brehmer et al., 2006a), multi-beam sonar data were recorded simultaneously on a professional analogue video format; then digitalized and analyzed in the laboratory to describe school sizes, shapes and movements (Brehmer et al., 2006b). 


\subsection{Contamination risk}

Lagoon ecosystem services include the provision of diverse food resources, in particular wild and aquaculture-reared fish and shellfish which depends on an unpolluted, high quality environment. Coastal lagoons accumulate contaminants from diverse sources, which are mainly trapped within their sediments but are repeatedly resuspended during the year and become available to the benthos (Castro-Jimenez et al., 2008; Kawakami et al., 2008). Therefore, non-specific ecotoxicological tests, which allow identification of toxicological effects on the benthos without any prior knowledge of the nature or the source of the contaminants, were conducted using sediment elutriates. For this, oyster larvae were exposed to the elutriates of 22 sediment samples from the three lagoons, all collected in 1999 using a van Veen grab. All details with regards the sampling and analytical methods are given in His et al. (1999). To produce the elutriates, $60 \mathrm{~g}$ of each sediment sample were mixed with $240 \mathrm{ml}$ of filtered reference water, shaken during eight hours and left to rest for eight extra hours before recovery of the supernatants. The oyster larvae, obtained by artificial fecundation, were placed in microplates (300 larvae per well) and exposed to the sediment elutriates for 24 hours at $23{ }^{\circ} \mathrm{C} \pm 1{ }^{\circ} \mathrm{C}$. At the end of this period, the larvae were fixed in $4 \%$ formaldehyde and the percentage of abnormality determined on the basis of a count of 100 larvae per well, i.e. per lagoon location.

To further assess potential in situ levels of contamination of lagoon bioresources, acetylcholinesterase specific activity was measured in the muscles of mussels (Mytilus galloproviencialis) sampled at different sites within Ingril and Prévost lagoons (Galgani et al., 1995). Because acetylcholinesterase enzymatic activity is depressed by neurotoxins such as organophosphorus pesticides, the use of this biomarker should allow identification of any significant exposure to anthropogenic pollution in the two lagoons.

\section{Results}

\subsection{Lagoon environmental conditions}

Meteorological conditions for 1999 and corresponding water temperatures and salinities in the three lagoons and their entrance channels are given in Appendix A. Autumn is characterized by an important shift in hydrological lagoon conditions, i.e. sharp decreases in temperature and salinity (Appendix A).

With regards water exchanges with the sea (Figure 3), the Fourier linear model used accounted for at least $74.3 \%$ of the diel variance in current velocity for each 'monthsite' combination. Site effect (lagoon channel) accounted for $47.1 \%$ of the total variance, but no significant effect of the sampling month was observed. The timing, the direction and the intensity of daily water exchanges with the sea varied according to both the lagoon and the month, with only rare periods of no water flow in the channels $\left(Y=0 \mathrm{~m} \mathrm{~s}^{-1}\right)$ (Figure 3). The highest variation in water exchanges was observed for the Ingril lagoon (with $Y$ varying from -1.02 to $0.83 \mathrm{~m} \mathrm{~s}^{-1}$ ), and the lowest in the Or lagoon (with $Y$ varying from -0.49 to $0.51 \mathrm{~m} \mathrm{~s}^{-1}$ ). Daily variations in water exchanges between the lagoon and the sea were regular over the three months of survey only for the Ingril lagoon, with two positive peaks within a $24 \mathrm{~h}$ cycle (Figure 3). This double peak of inflowing currents was also observed in October in the channel of the Or lagoon but never in that of the Prevost lagoon. Global average $Y$ values over the three months 
tested indicated that water current was mostly outflowing in the channels of the Prevost (average $Y=-0.48 \mathrm{~m} \mathrm{~s}^{-1}$ ) and the Or (average $Y=-0.15 \mathrm{~m} \mathrm{~s}^{-1}$ ) lagoons, while inflowing currents dominated (average $Y=0.08 \mathrm{~m} \mathrm{~s}^{-1}$ ) in the channel of the Ingril lagoon.

These inter-lagoon differences in water renewal played an important role in determining the quality of environmental conditions in each lagoon (Table 1). With a global ranking of 4/5 (LEMN diagnostic indicator: medium), Ingril lagoon was moderately eutrophic. Its water quality was medium (4/5) but phytoplankton abundance was good (3/5) and macrophytes coverage, although limited to a few species, included beds of phanerogams, present in several parts of the lagoon (4/5). Sediment quality was good on average (3/5), with the lowest RedOx potential ( $-94 \mathrm{mV}$ on average) of the three lagoons. As a result, benthos diversity and production was very good (2/5) in this lagoon.

Environmental quality in the two other lagoons was much poorer (Table 1). With a global ranking of 5/5 (LEMN diagnostic indicator: bad), the Prévost lagoon, which receives inputs from both the Lez and the Mosson rivers and has limited water exchanges with the sea was highly eutrophic. Water quality was medium (4/5) in this lagoon but elevated concentrations of nitrates and phosphates resulted in excessive phytoplanktonic production (5/5) and recurrent monospecific blooms of macroalgae during the summer. Both of these cause anoxic events, which explains the bad quality $(5 / 5)$ and the high RedOx potential ( $-245 \mathrm{mV}$ on average) of the sediment in this lagoon. Accordingly, its status was only medium (4/5) with regards both macrophytes and invertebrates.

Because of the limitation of its exchanges with the sea and the importance of its riverine inputs, the Or Lagoon was the most degraded of the three lagoons (Table 1), with a global ranking of $5 / 5$ (LEMN diagnostic indicator: bad). Water column quality was bad (5/5), mainly due to high concentrations of dissolved nitrogen and phosphorus. As a result, there was excessive phytoplankton production throughout the year; the succession of blooms thus obscured the water column, limiting macrophytes diversity and abundance (4/5). Sediments were heavily enriched with nitrogen and phosphorus, and exhibited a high RedOx potential $(-166 \mathrm{mV})$ due to plankton sedimentation and degradation by bacteria. Their poor quality (5/5) was responsible for the limited $(4 / 5)$ diversity and productivity of invertebrate communities despite the high primary production.

\subsection{Fish species diversity and abundance}

Annual fish diversity was similar for the three lagoons, with total species richnesses of 16, 15 and 14 species in the Or, the Ingril, and the Prévost lagoons, respectively. Scientific surveys underlined inter-lagoons differences in the total abundance of commercially important fish species, with high values for both the Or and the Prévost lagoons (of 1011 and $1017 \mathrm{~kg} \mathrm{day}^{-1}$, respectively), but a much lower estimate (475 kg day $^{-1}$ ) for the Ingril lagoon. Among the five species surveyed, eels (Anguilla anguilla) were dominant in terms of biomass irrespective of the lagoon, and despite important catches of mullets (Mugilidae) and sand smelts (Atherina boyeri) in spring in the Prévost and the Or lagoons, respectively (Figure $4 a$ ). Fish catch composition varied greatly according to the study site and the period of the year (Figure 4b). Seasonal trends were marked and comparable in the three lagoons, with a maximum diversity of fish (Appendix C) and significantly higher $(P<0.05)$ scientific and commercial fish CPUEs in the autumn (Figure 4b). 


\subsection{Fish fluxes across the channels}

Over the three days of acoustic tracking in the autumn, i.e. during the period for maximum fish emigration from the lagoons, a total of 22364,37765 and 33712 individual fish were recorded in the channels of the Or, the Prévost and the Ingril lagoons, respectively. When taking into account lagoon surface area, this represented respectively 7,99 and 61 fish ha $^{-1}$ (Figure 5a). The intensity of fish incursions in lagoon entrance channels was thus not linked to lagoon size and much lower for the Or than in the two other lagoons.

Irrespective of the lagoon, the number of fish detected in the channels was lower in September than in the two other months. Unexpectedly, fish flow was directed toward the lagoon irrespective of the month in the Or lagoon (net flows of 20 to 183 fish h$^{-1}$ ), and in October for the Prévost and the Ingril lagoons (net flows of 14 to 61 fish $^{-1}$ ). They were directed toward the sea in September and November in the Prévost and the Ingril lagoons, but with low values (net flows of -7 to -20 fish $\mathrm{h}^{-1}$ ). Furthermore, fish flows were higher by day than by night, with sometimes opposite directions during these two periods (Figure 5b).

\subsection{Bioresources exposure to pollutants}

The percentage of abnormal development was generally low $(<25 \%)$ in the oyster larvae exposed to sediment elutriates of the three lagoons, but elevated values at some sites indicated localized peaks of sediment toxicity (Figure 6a). Maximum sediment toxicities were observed in the Prevost lagoon, near the mouths of the Lez and the Mosson rivers ( $>50 \%$ of larval abnormalities), and elevated values also occurred near the mouth of the Salaison river $(37 \%)$ in the Or lagoon and along the Rhône-Sète canal (20-30\%) in all lagoons.

Mussel acetylcholinesterase activities in the Ingril and the Prevost lagoons confirmed the existence of inter and intra-lagoon differences in contamination levels (Figure 6b). In the Prévost Lagoon, all recorded acetylcholinesterase activity rates were under 0.15 units, indicating a high exposure to toxicants in this lagoon, with a maximum at the station near the Rhône-Sète Canal. For the Ingril lagoon, all values were above 0.15 units, with only the stations situated along the Rhône-Sète canal and in the northern part of the lagoon showing low acetylcholinesterase activity rates ( $<0.10$ units).

\section{Discussion}

\subsection{Ecological status of the three lagoons}

Global lagoon environmental status based on the LEMN diagnostic tool differed among the three lagoons. The Ingril lagoon was in a medium quality state $(4 / 5)$, whereas the Prévost and the Or lagoons were in a bad state (5/5). This difference mainly resulted from the differences in anthropogenic inputs to the three lagoons, the high levels of eutrophication observed in the Or and the Prévost lagoons resulting from many years of high nitrogen and phosphorus loads due to the numerous urban sewage treatment plants present on their watershed. The Ingril lagoon, which does not receive direct inputs from any major city, had a much better water and sediment quality with regards to eutrophication. This was also linked to the more marked water fluxes in its channel when compared to that of the two other lagoons, as these fluxes determine the extent 
of water renewal in the lagoon. Wind, rain, and atmospheric pressure are typically the main forcing factors of sea-lagoon exchange dynamics (Johnson, 1998). In the three lagoons studied, the low Mediterranean tidal variations seemed to be the main forcing in the Ingril lagoon (Figure 3) but the lowest variability in lagoon channel water fluxes for the two other lagoons suggesting that lagoon size and riverine inflow also played an important role. This should be confirmed soon by the hydrodynamics MARS-3D model (Lazure and Dumas, 2008), which provides accurate assessments of water renewal under several tidal and meteorological conditions and is currently under development for all three lagoons.

The extent of water renewal in the lagoons strongly affects lagoon characteristics, particularly oxygen deficiency in the water column and the sediments. The limited water renewal in both the Or and the Prevost lagoons thus explains the bad states $(5 / 5)$ found for their sediments. However, our results illustrate that sediment quality assessment in the lagoons should not be limited to the measure of their eutrophication status. The predominance of phytoplankton in the more eutrophic Or lagoon and of macroalgae in the Prévost lagoon resulted in a much higher sediment RedOx potential in the latter. Lagoon sediment status with regards eutrophication also did not fully match that obtained with regards pollution, which suggested that sediment toxicity essentially occurred in the Prevost lagoon, due to important pollution loads associated with the two main rivers running through the nearby city of Montpellier.

Sediment and primary production quality with regards eutrophication strongly influenced macrobenthos diversity and density in the three lagoons (Mouillot et al., 2005). Yet it has no impact on fish taxonomic diversity, with very similar values of species richness between the three lagoons. This result contradicts Helminen et al.'s (2000) findings for the Finnish lakes, but fits well with Kemp et al.'s (2005) results for Chesapeake Bay. Fishing pressure and practices are also likely to impact fish diversity (Albaret and Lae, 2003) as well as fish fluxes between the sea and the lagoon. Eels and Mugilidae dominated all the fish communities, their presence or absence therefore cannot be considered as a good indicator of lagoon eutrophication status. However, the presence of Atherina boyeri, a non-migratory planktivorous species that appears to be well established in highly eutrophicated lagoons such as the Or and the Prévost lagoons potentially could be an indicator of bad eutrophication status, as this species was seldom found in the Ingril Lagoon (Figure 4a).

With regards fish fluxes, the global net fluxes for the three lagoons do not show an obvious migration process toward the sea in the autumn. Although the Ingril and the Prévost lagoons differ in their eutrophication status, no difference in global fish transfer was detected between them. When divided by lagoon area, the numbers of fish passing through each of the three channels suggest the presence of lagoon-specific differences in fish export. In comparison with the Or lagoon, the Prévost and the Ingril Lagoons, although smaller, had higher fish fluxes within their channels. These results suggest that the Or lagoon had the lowest fish density and lower fish exchanges with the Sea. This might be linked to the fact that its connection channel is longer $(0.7 \mathrm{nmi})$ than that of the two other lagoons $(0.2 \mathrm{nmi}$ for both the Ingril and the Prévost), and is connected with another channel.

Monthly variations in CPUEs confirmed the seasonal variability in fish catchability in the lagoons (Bach et al., 1992). Small-scale fishermen reported higher catches in the autumn, which corresponds to the period when fish migrate back to the sea to spawn (e.g. Anguilla anguilla, Sparus aurata). During the winter and the summer, i.e. periods 
with supposedly few migrations, commercial landings decreased. With regards eutrophication status, both the Or and the Prevost lagoons (ranked as poor) had a similar fish abundance crossing their channel (over $1010 \mathrm{~kg} \mathrm{day}^{-1}$ ), whereas Ingril (ranked as medium) had more than two times less, at over $400 \mathrm{~kg} \mathrm{day}^{-1}$.

The biomarker acetylcholinesterase discriminated the Prevost lagoon from the others in terms of the impact of neurotoxic carbamates or organophosphates (Rickwood and Galloway, 2004), which cause a decrease in enzyme activity. The decrease of enzyme activity was in the same range as other transition waters studied within the context of Water Framework Directive (Hagger et al., 2008). The levels of activity also confirmed the influence of the Rhône-Sète Canal with an extension limited to the south of the canal. This was confirmed by the toxicity of sediments that is related to presence of contaminants. Overall, the toxicity level found in our study was low in comparison with other sites studied in other regions (e.g. urban and industrial waste outlets), but it was substantial in the mouths of the Mosson and Lez rivers where respectively 50 and $100 \%$ abnormal larvae were measured, although the test used is non-specific and measures the overall impact of contaminants. Andral et al. (2004), demonstrated the occurrence of metals, hydrocarbons, and polychlorobiphenyls (PCBs) in the Or Lagoon and the presence of mercury, polyaromatic hydrocarbons, and pesticides in the Prévost Lagoon. Under these conditions, the full set of results obtained from ecotoxicological approaches appear to be consistent with the information available on chemical contamination.

\subsection{Implications for the improvement of lagoon ecological status assessment}

Improving the assessment of lagoon ecological status requires a multifaceted approach. It is not easy to involve all components of an ecosystem in field investigations. However, these results demonstrate the need for combining at least all the techniques used here in order to evaluate lagoon status precisely.

Ecotoxicological studies (e.g. Morrison et al., 1997), which allow assessment of marine pollution in lagoons (His et al., 1999), must be conducted. Our results show that they allow precise identification of contaminated areas within lagoons by combining the use of pollution biomarkers and experimental exposure to sediment elutriates. They must, however, be integrated with other types of environmental data for better management of lagoon ecosystems and their resources, because they can be interpreted in terms of success potential for the recruitment for young fishes and aquaculture production in each lagoon.

Fishing methods allow biological sampling and comprehensive estimation of fish abundance and diversity. Yet, complementary investigations of lagoon fish, including life history data for the main representative populations, are needed. New indicators of fish resources are needed as well. Such indicators could use a classification by functional group (Dumay et al., 2004) derived from the results of both fishing and acoustic observations (Brehmer et al., 2006a). Hence, because acoustic tracking of fish is non-intrusive, it provides valuable non-destructive data on pelagic fish populations, such as the size and shape of fish shoals (Brehmer et al., 2006a) and also fish sizes (Love 1977; Guillard et al., 2004). These kinds of data allow researchers to better analyse anthropogenic effects on the management of lagoon pelagic fish populations.

In this study, viruses and bacteria, which are also important components of marine ecosystem (Noble and Fuhrman, 1998; Kemp and Aller, 2004), were not taken into account. Lagoon birds (Cowx, 2003) and recreational fisheries (Cooke and Cowx, 2004) can also impact fish population densities, and ideally should be investigated. 
Accurate assessment of lagoon ecological status requires continuous real-time recording for coordinated integrated management. Hence, lagoon environments can change on small temporal scales, and fish migrations are difficult to estimate accurately without covering the whole migration period. In such variable systems, which are further complicated by nonlinear feedback mechanisms (Kemp et al., 2005), a continuous observation method is needed to detect early-warning signals before critical changes occur (Scheffer et al., 2009). Apart from the collection of data on lagoon fish, sediment and macrobenthos status, which all necessitate in situ scientific sampling campaigns, an automated procedure could be considered. The use of autonomous data acquisition systems based on several fixed multisensor stations in all the lagoons and their channels could provide continuous, near real-time monitoring of various environmental parameters including fish migrations. For this a simple data logger could be set up to export binary files (scientific output) from both echosounder (Fabi and Sala, 2002) and multibeam sonar systems (Brehmer et al., 2008). Satellite data transmitted via the GPRS telecom system would allow the use of a remote web-based Geographic Information System with representation in near real time. Such automation of data collection would permit the creation of a standardized historical database, which is essential for ecological studies and for management and conservation purposes. This type of ecosystem-based analysis would provide a better understanding of lagoon ecosystems, which in turn would help generate more efficient integrative management. Such work focused on a restricted ecosystem could be then adapted and extended to wider-scale systems.

\subsection{Model of organizational lagoon management}

A rational management plan needs to coordinate scientific investigations following integrative analysis of potential uses of lagoons, taking into account their impact on the ecosystem organization and functioning, and to prioritize uses for each lagoon, i.e. between conservation, restoration, and/or several types of sustainable exploitation. In such a way a manager could readdress the assessment tools for the establishement of a specific lagoons status in accordance with the expected societal benefits e.g. encourage fishing activity in eutrophic lagoons and avoid it in less eutrophic ones which are more suitable as nursery sites. The main goal of lagoon near real-time monitoring is to centralize all scientific information (Michener et al., 1997) into a single observatory which to date has not been achieved. Such an approach applying GIS representation, diagnostic indicators, and risk estimators, would simplify and reduce the delay in management decision making. Such organization would improve the interactions and feedback between decision makers, managers, and researchers. Moreover, integrating the full range of measured parameters might lead to detection of new diagnostic indicators and provide a synthetic control panel for each lagoon. A 'holistic' approach towards a global ecosystem health status (Figure 7) would integrate the eutrophication status, the ecotoxicological status, and the fish and bird populations through their diversity, abundance, behaviour, and life history traits. Given the multiple sources and types of anthropogenic perturbations experienced by coastal lagoons (e.g. global warming, fishing pressure, chemical contamination, nutrient loadings, invasive species, etc., (Figure 7)), there is a consensus among researchers to assess and manage such ecosystems using multi-indicators and synthetic indices that embrace many aspects of ecosystem health (Cairns et al., 1993, Hilty and Merenlender, 2000; Mistri et al., 2007, Borja and Dauer, 2008). When there are a set of heterogeneous indicators it is necessary to weight them to establish a synthetic index (Fano et al., 2003). This index must then provide a classification that distinguishes between different lagoons. In our case, the innovation would be to include many sources of information that are independent into a multifaceted framework (Villeger et al., 2008). Usually, indices 
based on multiple indicators rely on the same kind of information; in contrast, we propose an approach that should deal with sediment, water, nutrient, flora, fauna and anthropogenic perturbations (pollution, fishing, etc.) within the same integrative framework to classify lagoons using various ecosystem aspects.

In lagoons, the variety of available indicators allows researchers to propose a variety of sensitive indicators that can be used by local authorities to make decisions (Figure 7). A diverse array of management plans has been issued by regional to federal decision makers on watersheds, lagoons, and coastal activities. The complexity of managing these ecosystems lies in the variety of lagoon characteristics, the spatio-temporal variation, the multiple types of uses, and the numerous possibilities of anthropogenic perturbations. Potential conflict of uses can arise from fishing, aquaculture activities, tourism, urbanization, and conservation/restoration missions. Applying an integrated co-management strategy (Borrini-Feyerabend et al., 2000) and integrating ecological knowledge for planning a sustainable approach (Botequilha Leitão and Ahern, 2002) is a way to solve this issue. Thus, clear objective(s) must be stated for each lagoon, taking into account scientific observations, socio-economic and bioeconomic studies (De Leo and Gatto, 2001). An efficient management approach needs to coordinate the scientific partners and to lead integrative studies (White et al., 2002; Plummer and Fitzgibbon, 2004), taking into account town and country planning from regional to federal legislations.

\section{Acknowledgements}

This work, dedicated to $\mathrm{Pr}$. Thang $\mathrm{Do} \mathrm{Chi}^{\dagger}$ who has coordinated the project, was realized through the XI CPER-LR, the Web based Lagoon Monitoring Network (Ifremer), and the axis 5 of Europole Mer. We are grateful to the local lagoon fishermen for use of their facilities and to the local authorities. Thanks are also due to all of the numerous researchers and students who participated in the field missions. We also thank John Baxter and the anonymous referees for their helpful comments.

\section{References}

Agardy T, Bridgewater P, Crosby MP, Day J, Dayton PK, Kenchington R, Laffoley D, McConney P, Murray PA, Parks JE, Peau L. 2003. Dangerous targets? Unresolved issues and ideological clashes around marine protected areas. Aquatic Conservation: Marine and Freshwater Ecosystems 13: 353-367.

Albaret JJ, Laë R. 2003. Impact of fishing on fish assemblages in tropical lagoons: the example of the Ebrie lagoon, West Africa. Aquatic Living Resources 16: 1-9.

Andral B, Stanisiere J, Sauzade D, Damier E, Thebault H, Galgani F, Boissery P. 2004. Monitoring chemical contamination levels in the Mediterranean based on the use of mussel caging. Marine Pollution Bulletin 49(9-10): 704-712.

Anonymous, 2002. Réseaux de suivie Lagunaire du Languedoc Roussillon: Bilan des résultats 2001. Ifremer Rapport RSL-02/2002, Sète, France. 
Bach P, Legendre P, Amanieu M, Lasserre G. 1992. Strategy of Eel (Anguilla anguilla): exploitation in the Thau lagoon. Estuarine and Coastal Shelf Science 35: 55-73.

Borrini-Feyerabend G, Farvar MT, Nguinguiri JC, Ndangang VA. 2000. Comanagement of Natural Resources: Organising, Negotiating and Learning-by-Doing. GTZ and IUCN, Kasparek Verlag, Heidelberg, Germany.

Borja A, Dauer DM. 2008. Assessing the environmental quality status in estuarine and coastal systems: Comparing methodologies and indices. Ecological indicators 8: 331 337.

Botequilha Leitão A, Ahern J. 2002. Applying landscape ecological concepts and metrics in sustainable landscape planning. Landscape and Urban Planning 59: 65-93.

Brehmer P, Mouillot D, Do Chi T. 2006a. Amphidromus fish school diel flow in two Mediterranean lagoons by combining sonar and fishing data. Journal of Experimental Marine Biology and Ecology 334(1): 139-150.

Brehmer $P$, Vercelli $C$, Gerlotto $F$, Sanguinède $F$, Pichot $Y$, Buestel $D$, Guénnegan $Y$. 2006 $\mathrm{b}$. Multibeam sonar three-dimensional monitoring of mussel culture grounds in open sea for management purpose. Aquaculture 252(2-4): 234-241.

Brehmer P, Georgakarakos S, Josse E, Trygonis V, Dalen J. 2008. Adaptation of fisheries sonar for monitoring large pelagic fish school: dependence of schooling behaviour on fish finding efficiency. Aquatic Living Resources 20: 377-384.

Cairns J, McCormick PV, Niederlehner BR. 1993. A proposed framework for developing indicators of ecosystem health. Hydrobiologia 263: I-44.

Castro-Jimenez J, Deviller G, Ghiani M, Loos R, Mariani G, Skejo H, Umlauf G, Wollgast J, Laugier T, Heas-Moisan K, Leaute F, Munschy C, Tixier C, Tronczynski J. 2008. PCDD/F and PCB multi-media ambient concentrations, congener patterns and occurrence in a Mediterranean coastal lagoon (Etang de Thau, France). Environmental Pollution 156(1): 123-135.

Clarke KR, Warwick RM. 2001. A further biodiversity index applicable to species lists: variation in taxonomic distinctness. Marine Ecological Progress Series 216: 265-278.

Conley DJ, Paerl HW, Howarth RW, Boesch DF, Seitzinger SP, Havens KE, Lancelot C, Likens GE. 2009. Controlling Eutrophication: Nitrogen and Phosphorus. Science 323(5917): 1014-1015.

Costanza R, D’Arge R, De Groot R, Farber S, Grasso M, Hannon B, Limburg K, Naeem S, O'Neill RV, Paruelo J, et al., 1997. The value of the world's ecosystem services and natural capital. Nature 387: 253-260.

Cooke SJ, Cowx IG. 2004. The Role of Recreational Fishing in Global Fish Crises. Bioscience 54(9): 857-859.

Cowx IG. 2003. Interactions between fish and birds: implications for management. Wiley-Blackwell, Oxford, UK.

De Leo GA, Gatto M. 2001. A stochastic bioeconomic analysis of silver eel fisheries. Ecological Applications 11(1): 281-294.

Dumay O, Tari PS, Tomasini JL, Mouillot D. 2004. Functional groups of lagoon fish species in Languedoc Roussillon, southern France. Journal of Fish Biology 64(4): 970983. 
Fabi G, Sala A. 2002. An assessment of biomass and diel activity of fish at an artificial reef (Adriatic Sea) using a stationary hydroacoustic technique. ICES Journal of Marine Science 59: 411-420.

Fano EA, Mistri M, Rossi R. 2003. The ecofunctional quality index (EQI): a new tool for assessing lagoonal ecosystem impairment. Estuarine, Coastal and Shelf Science 56: 709-716.

Galgani F, Bocquené G, Burgeot T. 1995. Acetylcholinesterase and EROD from Acanthurus bahianus from Martinique Island (French West Indies). Biomarkers 1: 208210.

Gonzalez L, Gerlotto F. 1998. Observation of fish migration between the sea and a mediterranean lagoon (Etang de l'Or, France) using multibeam sonar and split beam echo sounder. Fisheries Research 35: 15-22.

Guillard J, Lebourges-Dhaussy A, Brehmer P. 2004. Simultaneous Sv and TS measurements on YOY fresh water fish using three frequencies. ICES Journal of Marine Science 61: 267-273.

Hagger J, Malcolm B, Lowe D, Leonard DR, Owen R, Galloway TS. 2008. Application of biomarkers for improving risk assessments of chemicals under the Water Framework Directive: A case study. Marine Pollution Bulletin 56(6): 1111-1118.

Helminen H, Karjalainen J, Kurkilahti M, Rask M, Sarvala J. 2000. Eutrophication and fish biodiversity in Finnish lakes. Verhandlungen. Internationale Vereinigung fur theoretische und angewandte Limnologie 27(1): 194-199.

Hilty J, Merenlender A. 2000. Faunal indicator taxa selection for monitoring ecosystem health. Biological Conservation 92: 185-197.

His E, Beiras R, Seaman M. 1999. The Assessment of Marine Pollution - Bioassays with Bivalve Embryos and Larvae. Advances in Marine Biology 37: 1-178.

Howarth W. 2008. The Marine Strategy Framework Directive. The Journal of Water Law 19: 95-97.

Johnson RW. 1998. The Handbook of Fluid Dynamics. CRC Press LLC, Boca Raton, USA.

Kawakami SK, Seidel JL, Elbaz-Poulichet F, Achterberg EP. 2008. Trace-Metal Biogeochemistry in the Mediterranean Thau Lagoon, a Shellfish Farming Area. Journal of Coastal Research 24(3): 194-202.

Kemp PF, Aller JY. 2004. Bacterial diversity in aquatic and other environments: what 16S rDNA libraries can tell us. FEMS Microbiology Ecology 47: 161-177.

Kemp WM, Boynton WR, Adolf JE, Boesch DF, Boicourt WC, Brush G, Cornwell JC, Fisher TR, Glibert PM, Hagy JD, et al. 2005. Eutrophication of Chesapeake Bay: Historical trends and ecological interactions. Marine Ecological Progress Series 303: 129.

Lazure P, Dumas F. 2008. An external-internal mode coupling for a 3D hydrodynamical model at regional scale (MARS). Advances in Water Resources 31: 233-250.

Krumme U, Saint-Paul U. 2003. Observations of fish migration in a macrotidal mangrove channel in northern Brazil using a 200-kHz split-beam sonar. Aquatic Living Resources 16(3): 175-184.

Losso C, Volpi Ghirardini A. 2010. Overview of ecotoxicological studies performed in the Venice Lagoon (Italy). Environment International 36: 92-121. 
Lotze HK, Lenihan HS, Bourque BJ, Bradbury RH, Cooke RG, Kay MC, Kidwell SM, Kirby MX, Peterson CH, Jackson JBC. 2006. Depletion, degradation, and recovery potential of estuaries and coastal seas. Science 312: 1806-1809.

Love $\mathrm{RH}, 1977$. Target strength of an individual fish at any aspect. Journal Acoustical Society of America 62(6): 1397-1403.

Michener WK, Brunt JW, Helly JJ, Kirchner TB, Stafford SG. 1997. Nongeospatial metadata for the ecological sciences. Ecological Applications 7(1): 330-342.

Mistri M, Munari C, Rossi R, Marchini A. 2007. Response of a Fuzzy Index of Ecosystem integrity (FINE) to water and sedimentary chemical data in two northern Adriatic lagoons. Chemistry and Ecology 23: 443-454.

Morrison RJ, Gangaya P, Naqasima MR, Naidu R. 1997. Trace Metal Studies in the Great Astrolabe Lagoon, Fiji, a Pristine Marine Environment. Marine pollution Bulletin 34: 353-356.

Mouillot D, Laune J, Tomasini JA, Aliaume C, Brehmer P, Dutrieux E, Do Chi T. 2005. Assessment of coastal lagoon quality with taxonomic diversity indices of fish, zoobenthos and macrophyte communities. Hydrobiologia 550: 121-130.

Nixon SW, Buckley BA, Granger SL, Entsua-Mensah M, Ansa-Asare O, White MJ, McKinney RA, Mensah E. 2007. Anthropogenic enrichment and nutrients in some tropical lagoons of Ghana, west Africa. Ecological Applications 17(sp5): S144-S164.

Noble RT, Fuhrman JA. 1998. Use of SYBR Green I for rapid epifluorescence counts of marine viruses and bacteria. Aquatic microbial ecology 14: 113-118.

Ona E. 1999. Methodology for target-strength measurements. ICES Cooperative Research Report, 235. ICES, Copenhagen, Denmark.

Oertli B, Biggs J, Céréghino R, Grillas $P$, Joly P, Lachavanne JB. 2005. Conservation and monitoring of pond biodiversity: introduction. Aquatic Conservation: Marine and Freshwater Ecosystem 15: 535-540.

Payraudeau S. 2002. Modélisation distribuée des flux d'azote sur des petits bassins versants méditerranéens. PhD thesis. University Montpellier II, Montpellier, France.

Plummer R, Fitzgibbon J. 2004. Co-Management of Natural Resources: A Proposed Framework. Environmental Management 33(6): 876-885.

Rickwood CJ, Galloway TS. 2004. Acetycholinesterase inhibition as a biomarker of adverse effect- a study of Mytilus edulis exposed to priority pollutant chlorfenvinphos. Aquatic Toxicology 67: 45-56.

Scheffer M, Bascompte J, Brock WA, Brovkin V, Carpenter SR, Dakos V, Held H, van Nes EH, Rietkerk M, Sugihara G. 2009. Early-warning signals for critical transitions. Nature 461: 53-59.

Schüring JS, Schulz HD, Fisher WR, Böttchers J, Duijnisveld WHM. 2000. Redox Fundamentals, processes and applications. Springer, Berlin, Germany.

Simmonds EJ, MacLennan DN. 2005. Fisheries acoustics. $2^{\text {nd }}$ edition, Fish and Fisheries Series, Chapman and Hall, London, UK.

Souchu $P$, Ximenes MC, Lauret M, Vaquer A, Dutrieux E. 2000. Mise à jour d'indicateur du niveau d'eutrophisation des milieux lagunaires Méditerranéens. Ifremer/Créocean/UMII Rapport du marché Public n989051 Tome I et II, 412 pp. Ifremer, Sète, France. 
Sousa A, Garcia-Murillo P, Morales J, Garcia-Barron L. 2009. Anthropogenic and natural effects on the coastal lagoons in the southwest of Spain (Donana National Park). ICES Journal of Marine Science 66: 1508-1514.

Villeger S, Mason N, Mouillot D. 2008. New multidimensional functional diversity indices for a multifaceted framework in functional ecology. Ecology 89: 2290-2301.

White AT, Courtney CA, Salamanca A. 2002. Experience with Marine Protected Area Planning and Management in the Philippines. Coastal Management 30(1): 1-26. 


\section{Tables}

Table 1. The lagoon eutrophication status was evaluated according five compartments: the water column (11 parameters); the phytoplankton (1 parameter); the benthic macrophytes (3 parameters); the sediment ( 3 parameters) and the Biological potentiality related to the invertebrate macrofauna characteristics (Souchu et al., 2000). The eutrophication status of the lagoons was characterized according to five levels ranging from excellent ' 1 ' (pristine ecosystem) to bad ' 5 ' (heavily eutrophic ecosystem), including very good ' 2 ', good ' 3 ', and medium ' 4 ' levels.

\begin{tabular}{|c|c|c|c|c|}
\hline Compartments & Measured parameters & Or & Ingril & Prévost \\
\hline Water Column & $\begin{array}{l}\text { Temperature; salinity; turbidity; dissolved oxygen; }\left[\mathrm{NO}_{3}\right] ;\left[\mathrm{NO}_{2}\right] ;\left[\mathrm{NH}_{4}\right] ;[\mathrm{PO} 4] ;[\text { Chla]; } \\
{[\text { Chla + pheopigments]; [total phosphorus]; [total nitrogen] }}\end{array}$ & 5 & 4 & 4 \\
\hline Phytoplankton & A bundance of cells $<$ and $>2 \mu \mathrm{m}$ & 5 & 3 & 5 \\
\hline Benthic macrophytes & Species composition; Species richness; Specific biomass density & 4 & 4 & 4 \\
\hline Sediments & [Organic matter content]; [total phosphorus]; [total nitrogen] & 5 & 3 & 5 \\
\hline Biological potentiality & Species richness and density of invertebrate macrofauna & 4 & 2 & 4 \\
\hline Global state & Five modalities from high (1) to bad (5) & 5 & 4 & 5 \\
\hline
\end{tabular}




\section{Figures}

Figure 1. (a) Map of the three lagoons studied (Ingril, Prévost, and Or). The Ingril and Prevost Lagoons are situated on the same watershed (bold line). All three lagoons are located in the same area along the Mediterranean coastline in the South of France. (b) Continuous monitoring of lagoon biotic and abiotic parameters using an autonomous network of fixed stations would allow for near realtime (satellite data transmission) decision making and for the centralization of lagoon information. The latter could be used to set up an observatory to improve feedback between decision makers, managers, and scientists. The red line indicates the position of the different watersheds.

(a)

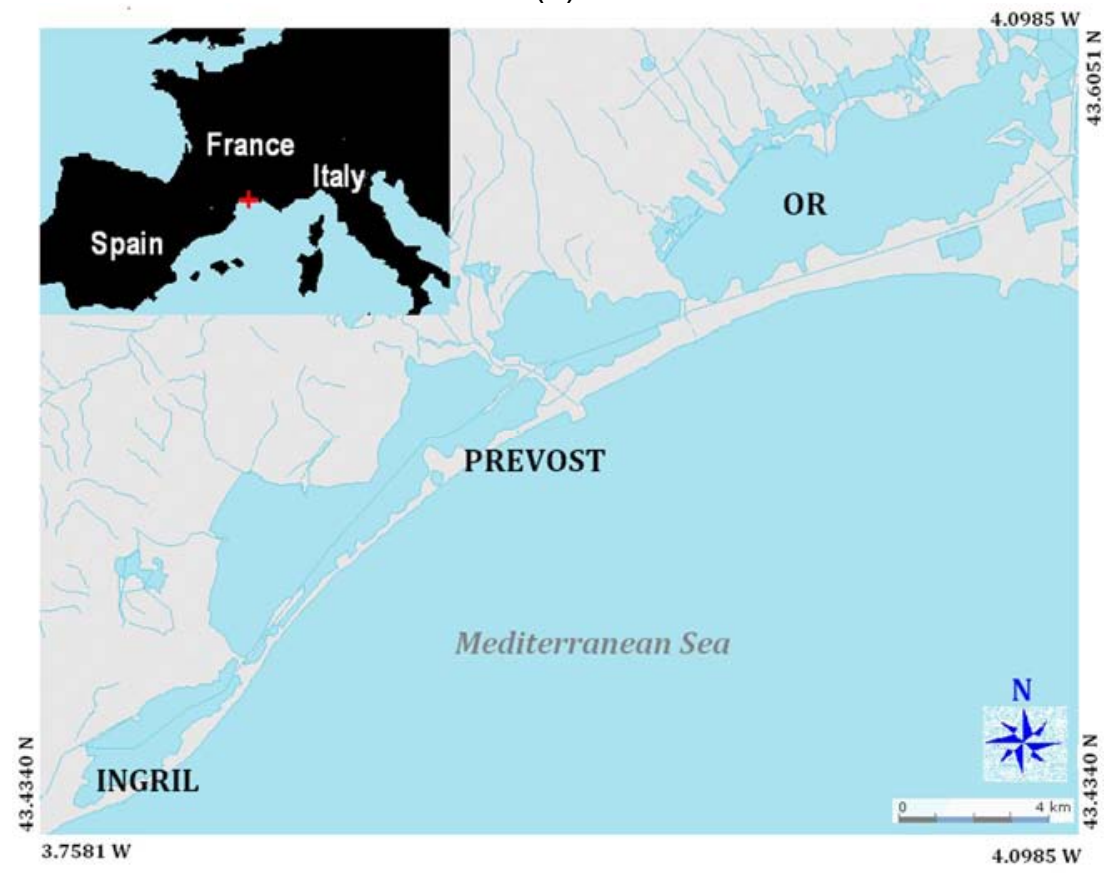

(b)

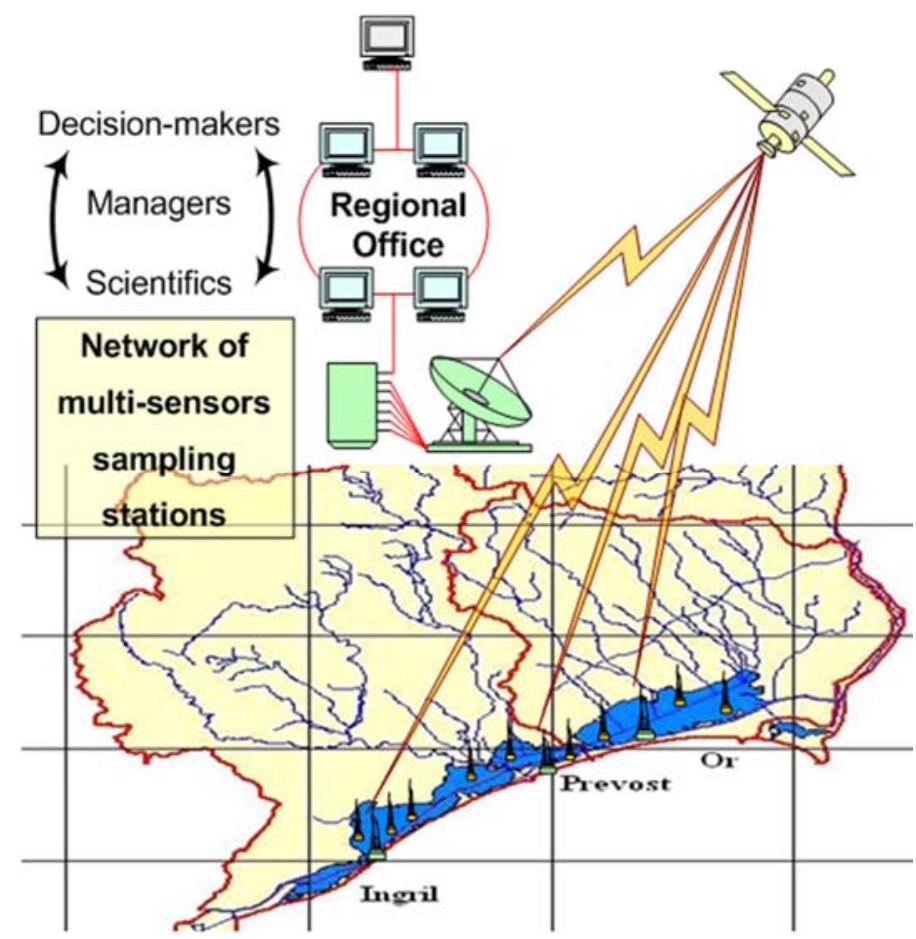


Figure 2. Scheme of the acoustic observation of fish migration in the lagoon channels and of the links between the lagoon (direction + ) and the sea (direction -). Two acoustic devices (a multibeam sonar ' 1 ' and a split beam echosounder ' 2 ') were used in horizontal beaming mode. The current velocity and direction were recorded by flow meters ' 3 '. Below, the diagram of the acoustics system for data collection, post-processing, and analysis of isolated fish and fish school transfer between the sea and the lagoon. The isolated fish were recorded by the horizontal split beam echosounder (HES) and the fish schools and shoals by the multibeam sonar (MBS). The data were processed using the software EP500 and Infobancs 2.0 and then stored in a database.
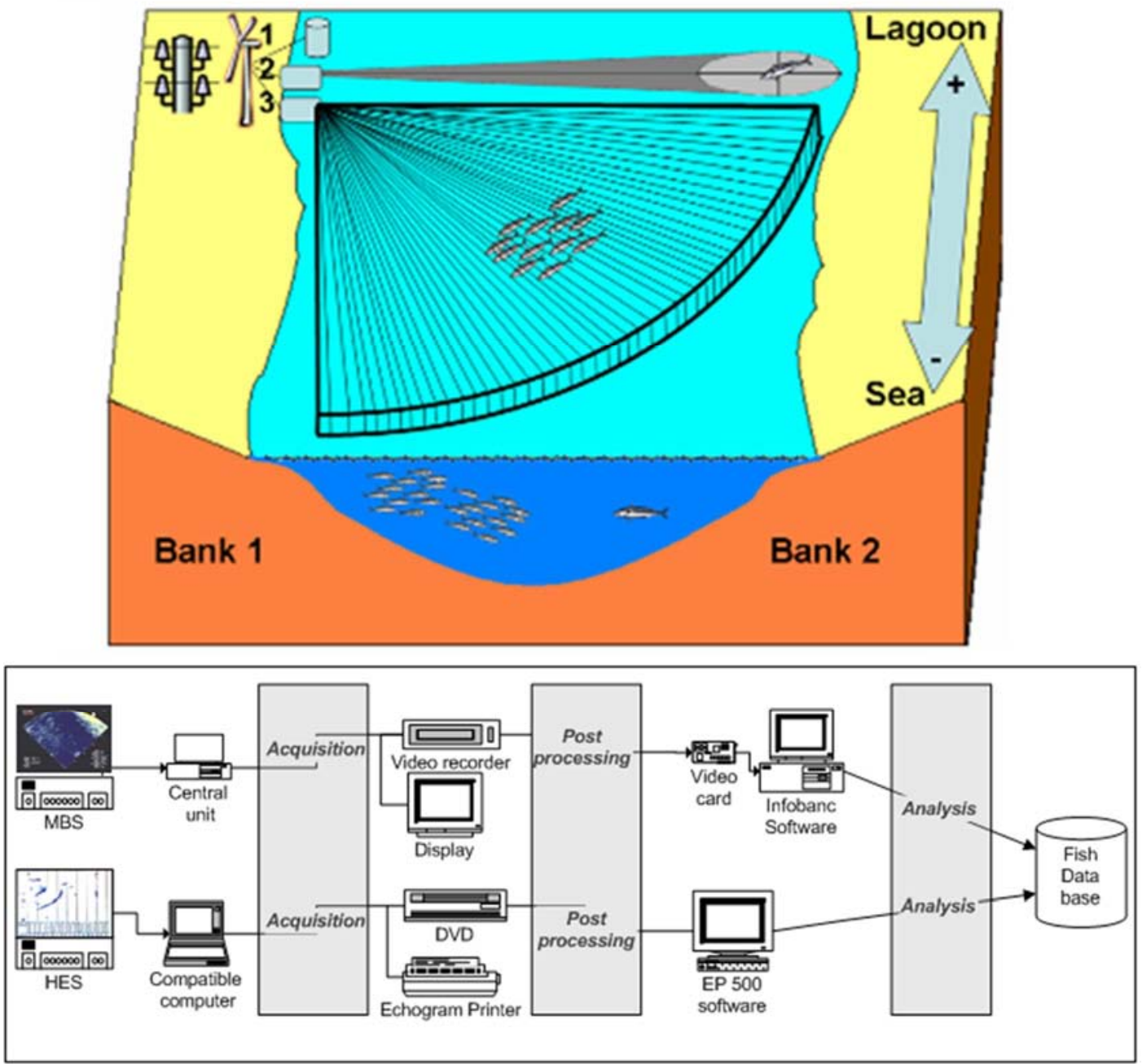
Figure 3. Fitted (curves) and observed values of current $\left(\mathrm{m} \mathrm{s}^{-1}\right)$ per period of observation [(September curve short dotted (observed values: $\times$ ); October curve continuous (observed values: $\circ$ ); November curve long dotted (observed values: +)] and per lagoon [(a), Or (b) Prévost, and (c) Ingril] for the Fourier series models. The positive values indicate upstream current and the negative values indicate downstream current.

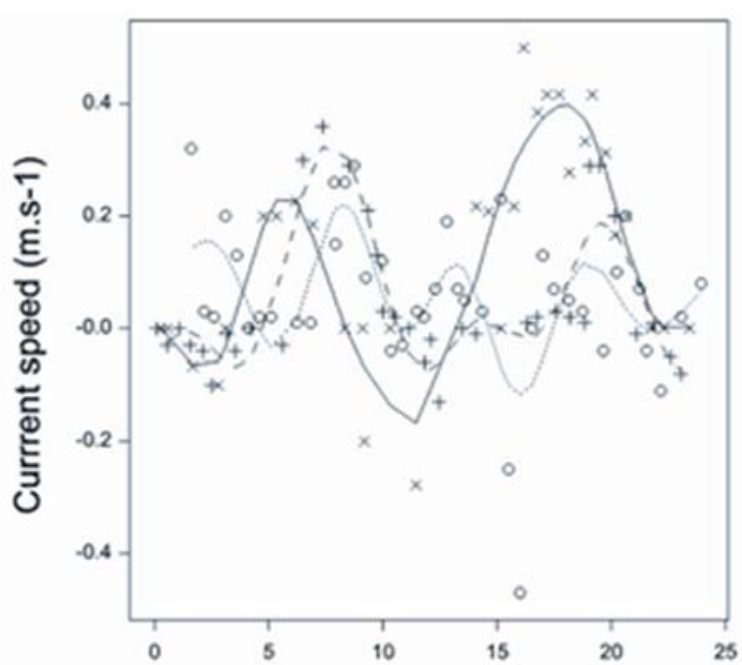

(a)
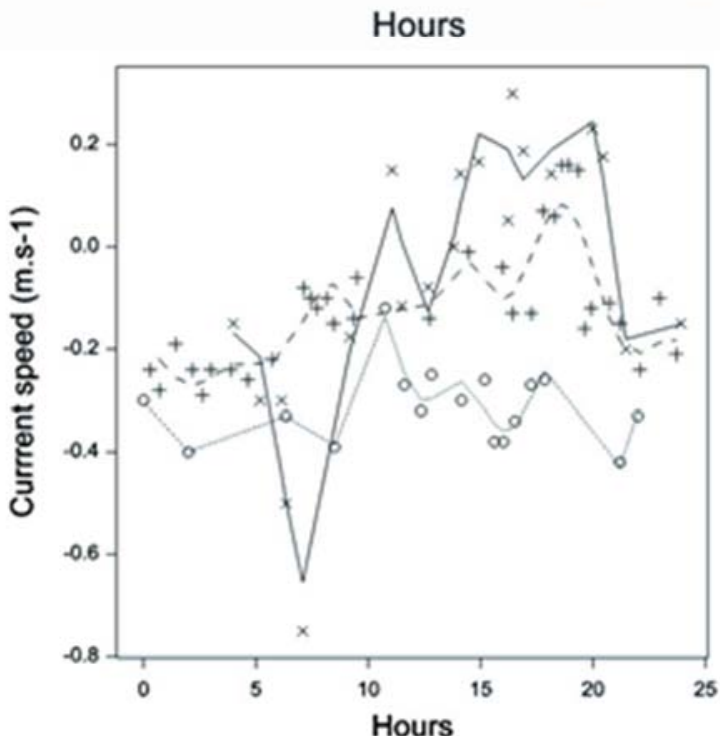

(b)

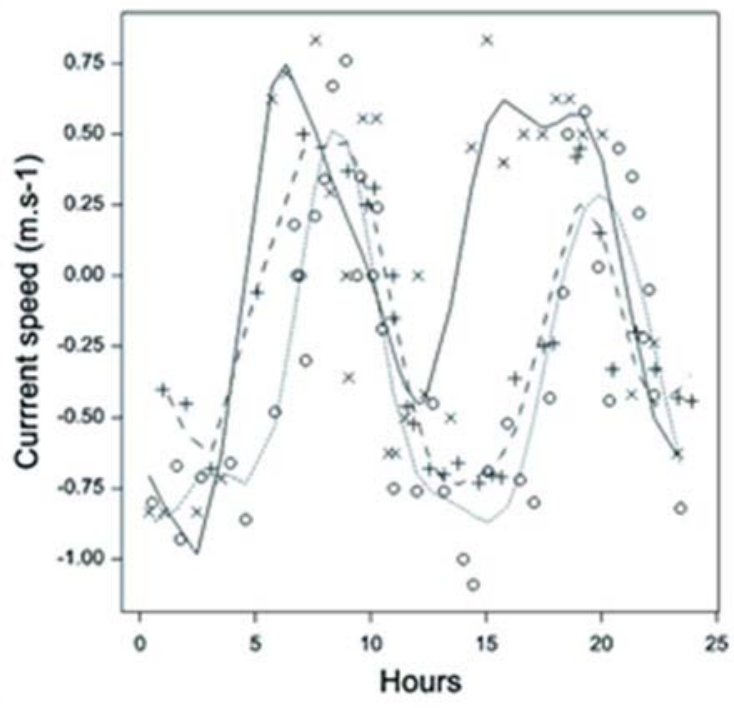

(c) - 
Figure 4. (a) Standardized catch per unit of effort $\left(\mathrm{kg} \mathrm{day}^{-1}\right)$ of the main fish species obtained by scientific fishing in 1999 for each lagoon (winter (grey); autumn (white); spring (black)) (see details in Appendix C). (b) Monthly percentage of the main species (Anguilla anguilla, Dicentrarchus labrax, Sparus aurata, and the Mugilidae) caught by commercial fishermen per lagoon (obtained from commercial landing in 1999).

(a)
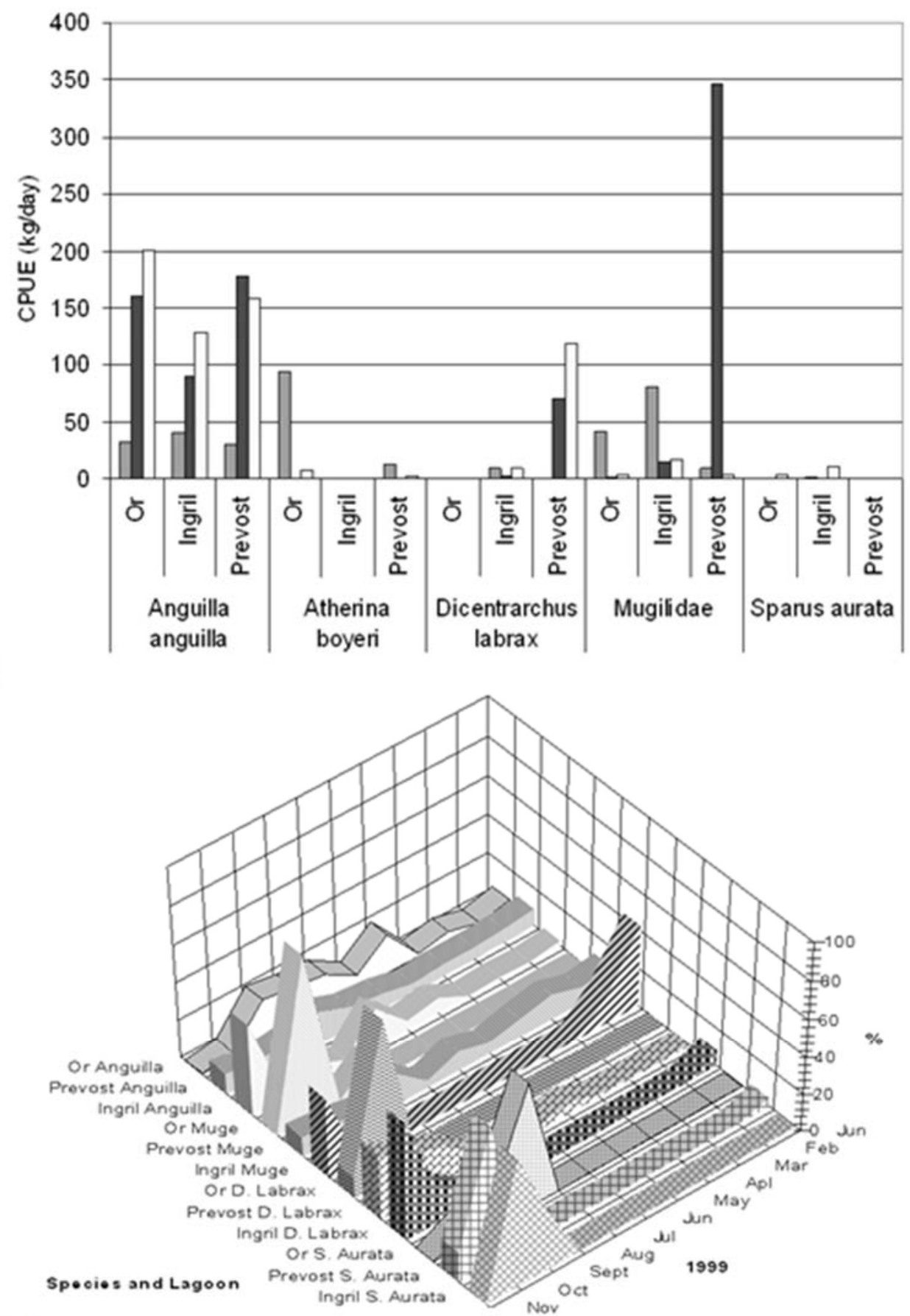

(b) 
Figure 5. (a) Number of fish detected by the echosounder in the three lagoon channels. On the second axis, the ratio of the number of fish detected in the lagoon area (in hectares) is shown. (b) Estimation of the average fish flow by hour on a daily cycle (positive toward the lagoon and negative toward the sea) and by hour for each lagoon during September (09), October (10), and November (11), in total (hatched) and according to the diel period (nocturnal in black, diurnal in grey).

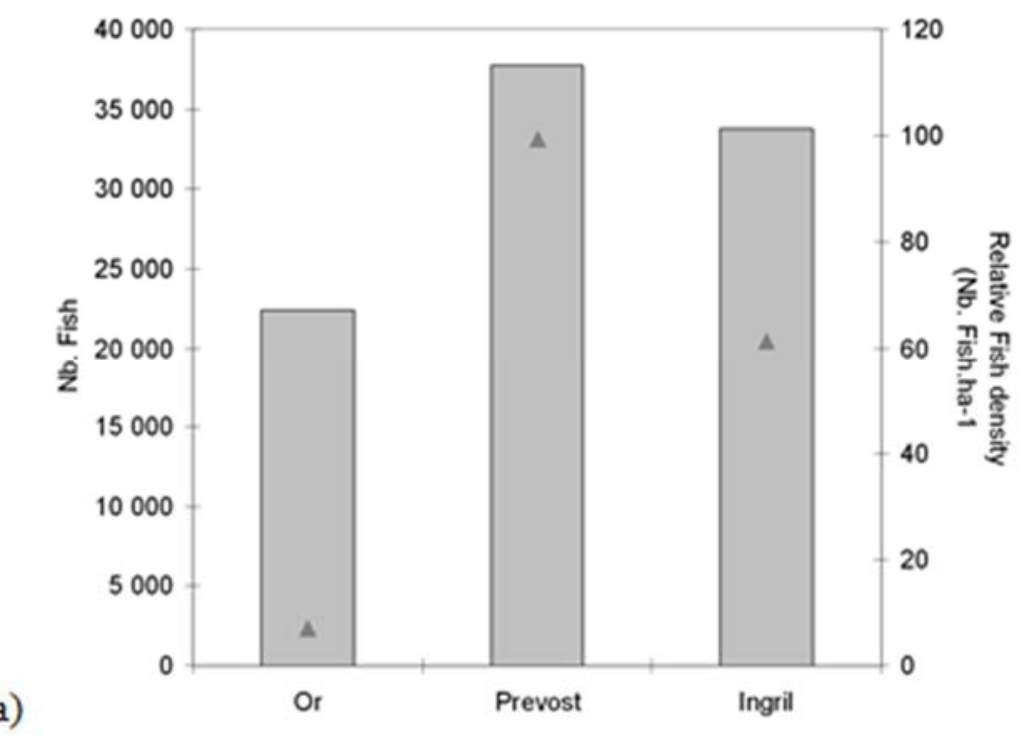

(a)

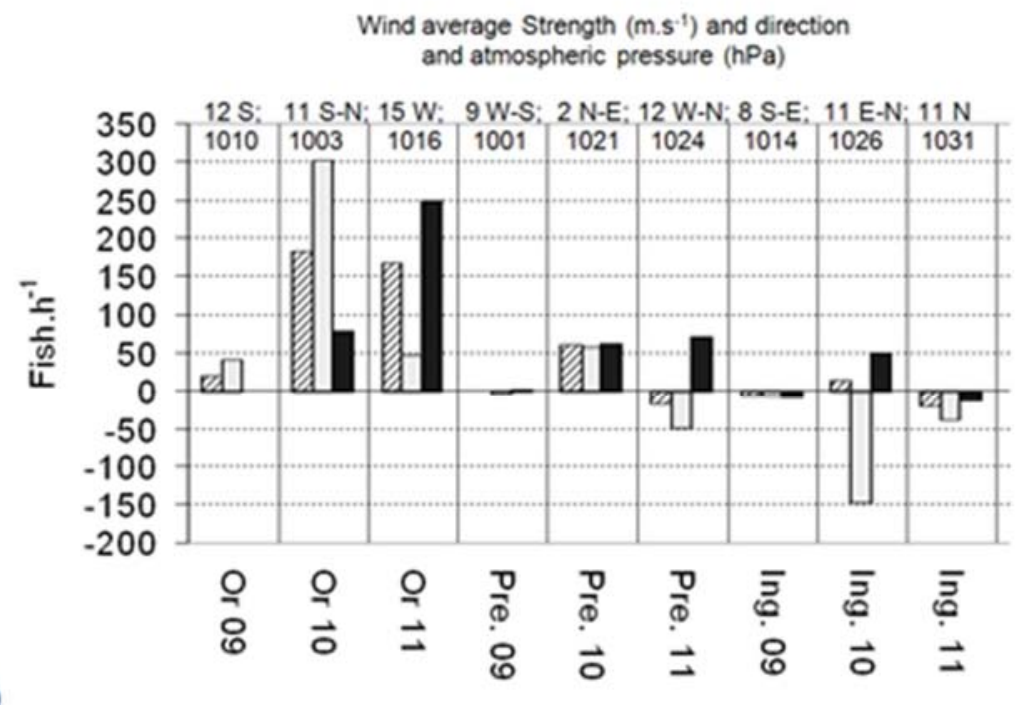

(a) 
Figure 6. (a) percentages of abnormality observed during mussel larval development when reared within sediment elutriates from 22 sites spread over the 3 lagoons and (b) Specific activity of acetylcholinesterase, measured as the optical density at $405 \mathrm{~nm}$ (released thiocholine) per minute and $\mathrm{mg}$ of extract proteins, in the muscle of mussels (Mytilus galloproviencialis) sampled in different sites of the Ingril and the Prévost lagoons
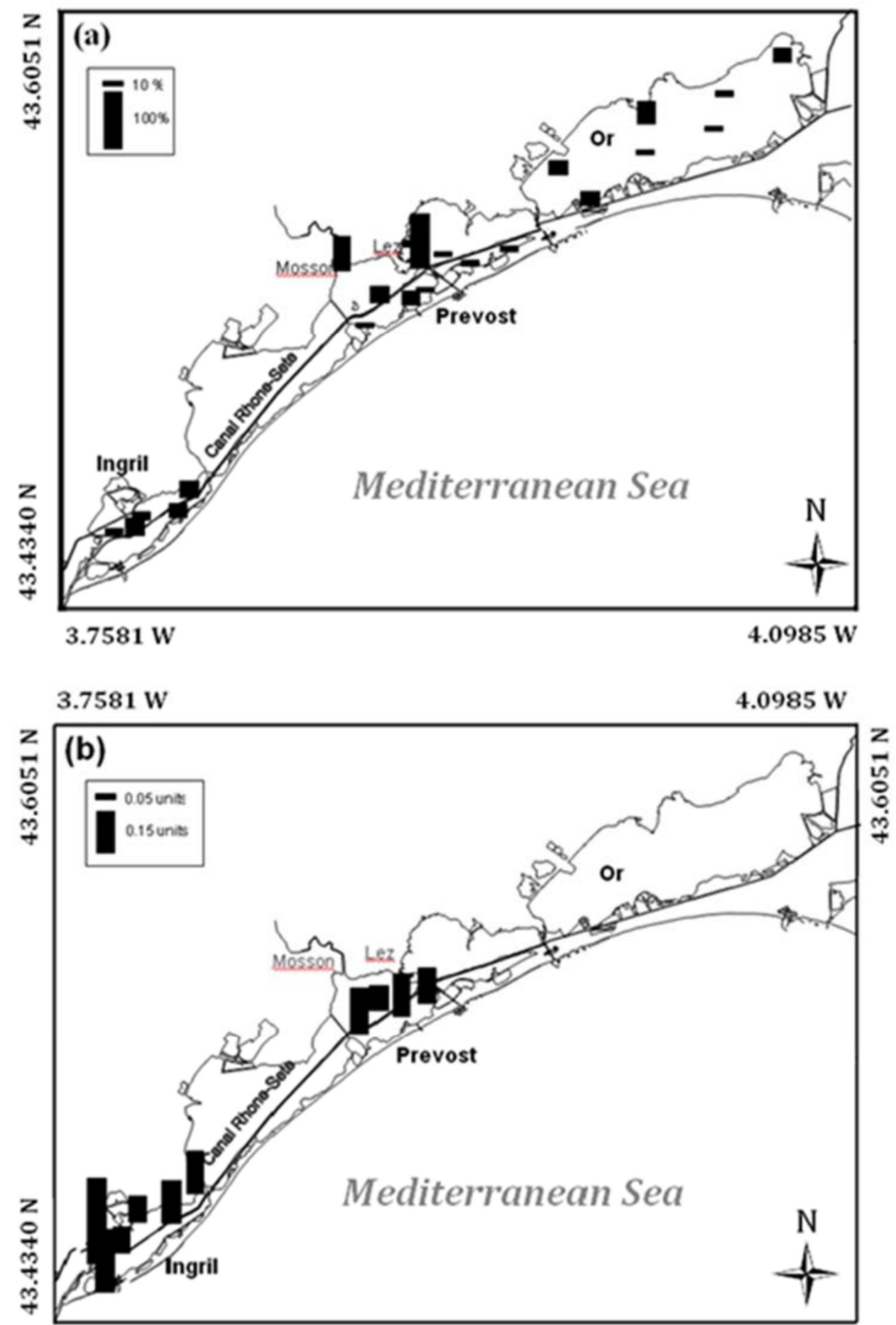
Figure 7. Scheme of the shallow water lagoon management organizational model. The difficulty in decision making (issues: conservation/restoration vs. exploitation) is due mainly to the complexity of the lagoon ecological organization and functioning (interaction between climate, habitat, and living resources) and the numerous possibilities for anthropogenic perturbations. Efficient feedback between manager and scientists, using diagnostic indicators and risk analysis, could lead to the realization of conservation or restoration with optimum efficiency; working with a clear objective for each lagoon and using ecological indicators from the major ecosystem compartments. Such organizational model must lead toward a global ecosystem health status and improve independent ecological indicators.

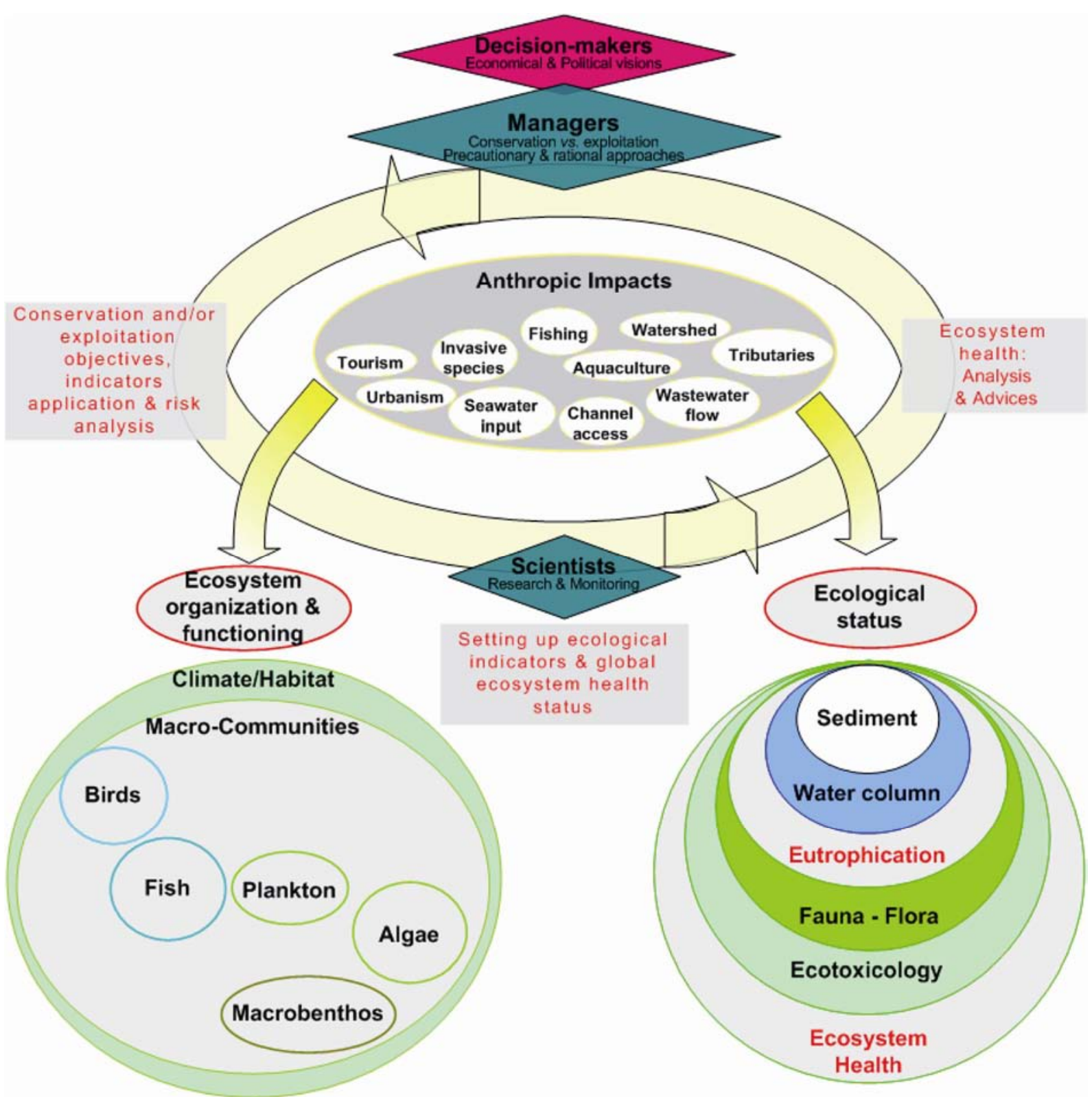

